\title{
PERANAN CUSTOMER SERVICE DALAM MENINGKATKAN PELAYANAN TERHADAP NASABAH PADA BANK NAGARI CABANG SITEBA PADANG
}

\author{
MIRAWATI, JHON FERNOS \\ Akademi Keuangan dan Perbankan "Pembangunan" \\ Jhonfernos@akbpstie.ac.id
}

\begin{abstract}
Customer Service is a communicator by providing all information and facilities to customers and also as a place to accommodate complaints, objections, or consultations between the interests of banks and the interests of customers. Customer Service plays a very important role in providing services and is intended to always connect with customers and keep the relationship good. This of course must be done because maintaining a good relationship with customers also means maintaining the bank's image so that the bank's image can continue to increase in the eyes of customers. That the role of Customer Service in increasing customer loyalty is very important through the services provided by the Customer Service department. Customer Service in the form of providing convenience to customers.
\end{abstract}

Keywords : Bank, Customer Service

\section{PENDAHULUAN}

Dalam prakteknya peranan Customer Service sangat penting untuk memberikan pelayanan terbaik untuk nasabah. Akan tetapi fakta di lapangan masih banyak nasabah yang mengaku tidak begitu puas dan mempunyai beberapa keluhan. Salah satunya di beberapa bank ada Customer Service yang kurang sabar menghadapi nasabah yang belum begitu mengerti bagaimana bertransaksi yang benar di bank. Artinya masih ada Customer Service yang kurang memiliki kesabaran menghadapi nasabah yang kurang mengerti tersebut. Padahal kita tau tingkat pendidikan nasabah juga berpengaruh untuk sebuah transaksi berjalan lancar atau tidak.

Saat ini perkembangan dunia usaha sangat pesat di berbagai sektor. Termasuk sektor perbankan di Kota Padang yang semakin hari semakin kompetitif. Perkembangan ini terkait dengan adanya dukungan pemerintah di sektor ekonomi nasional dan adanya berbagai kemudahan yang diberikan oleh pemerintah demi menopang perkembangan dunia usaha tersebut. Salah satunya dengan menciptakan cara atau suasana yang baik bagi perkembangan usaha di bidang perbankan di Indonesia. Hal ini juga dibuktikan dengan banyaknya bank baru yang membuka kantor cabang di Sumatera Barat, terutama di Kota Padang. 
Peranan Customer Service (CS) dalam meningkatkan pelayanan pelanggan terhadap nasabah di bank atau instansi lain, karena pelayanan pelanggan yang bermutu merupakan kunci sukses dan dasar untuk membangun keberhasilan di suatu perusahaan atau instansi tertentu.

Setiap perusahaan mempekerjakan petugas pelayanan pelanggan (Customer Service) dalam memberikan pelayanan terhadap nasabah secara baik dan memuaskan. Oleh karena itu peranan Customer Service sangat penting dan merupakan tulang punggung kegiatan operasional dalam perbankan. Tanpa adanya Customer Service, maka akan sangat berpengaruh terhadap perkembangan bank atau perusahaan tersebut.

Pelayanan nasabah atau Customer Service pada sebuah bank merupakan jasa pelayanan yang diberikan oleh bank kepada nasabah pada khususnya dan masyarakat pada umumnya yang berkaitan dengan kegiatan usaha dan operasional bank sehari-hari, dengan kondisi persaingan disektor jasa yang semakin meningkat itu, perusahaan perbankan sebaiknya terus meningkatkan Customer Service. Untuk meningkatkan citra perbankan maka diperlukan karyawan yang siap melayani setiap kebutuhan

nasabahnya. Secara umum pengertian Customer Service adalah setiap kegiatan yang diperuntukkan atau ditujukan untuk memberikan kepuasan kepada nasabah, yaitu dengan melalui pelayanan yang bermutu yang nantinya dapat memenuhi keinginan dan kebutuhan setiap nasabah.

Peran Customer Service yang bermutu hanya bisa dipahami dari sudut pandang nasabah. Nasabah memberikan penilaian terhadap tingkat pelayanan tersebut dengan berbagai cara, salah satunya dengan melihat dan menilai sistem dan prosedur yang telah tertata. Kemudian keahlian Customer Service menyampaikan produk dan pelayanan yang berhubungan dengan bagaimana penyedia pelayanan dalam menggunakan sikap, prilaku dan kemampuan lisan dalam berinteraksi dengan pelanggan.

Selain bank, Perusahaan yang lain sebagai sebuah lembaga bisnis yang mengejar keuntungan atas kegiatan yang dijalankannya, juga harus memperhatikan pelayanan yang diberikan agar kepuasaan pelanggannya dapat tercapai.

Menurut Munir (1991), pelayanan adalah aktivitas yang dilakukan seseorang atau sekelompok orang dengan landasan faktor material melalui sistem, prosedur dan metode tertentu dalam rangka memenuhi kebutuhan orang lain sesuai dengan haknya. Maka, pelayanan adalah suatu kegiatan yang terjadi dalam interaksi langsung dengan manusia atau mesin secara fisik untuk menyediakan kepuasan konsumen.

Agar pelayanan yang diberikan berjalan dengan baik, maka interaksi antara nasabah dan Customer Service harus berjalan dengan baik. Interaksi ini adalah komunikasi antara customer service dengan nasabah, meliputi apa yang mereka katakan, bagaimana mereka mengatakan, apa yang mereka lakukan dan bagaimana mereka melakukan interaksi antara nasabah dengan peralatan teknis dan fisik yang ada dalam organisasi, seperti pengisian formulir/ dokumen, cara pembayaran dan lain sebagainya.

Dalam memberikan pelayanan, Customer Service bank selalu dituntut agar dapat memuaskan nasabah tanpa melanggar harga diri atau etika. Adanya pelayanan yang baik itulah yang membuat nasabah merasa senang dan dihargai sebagai pihak yang membutuhkan jasa, sehingga nasabah tersebut akan kembali lagi dan melanjutkan hubungan bisnis dengen bank atau perusahaan tersebut. Kemudian nasabah tersebut akan 
menceritakan kepuasan dan kebaikan pelayanan yang diperoleh kepada rekan atau nasabah yang lain

Sehubungan dengan uraian di atas, penulis tertarik untuk mengamati pelayanan yang diberikan oleh Customer Service di Bank Nagari Cabang Siteba padang. Karena Customer Service benar-benar dituntut untuk memberikan yang terbaik kepada nasabah. Untuk memberikan gambaran yang lebih jelas tentang apa dan bagaimana pelayanan yang baik bagi seorang nasabah dan untuk menambah pemahaman masyarakat apa dan bagaimana sikap Customer Service tersebut, maka penulis tertarik untuk membahas dan menuangkannya dalam bentuk tugas akhir yang diberi judul "Peranan Customer Service Dalam Meningkatkan Pelayanan Terhadap Nasabah Pada Bank Nagari Cabang Siteba Padang"

Adapun yang menjadi permasalahan yang akan penulis bahas dalam penelitian ini yaitu : "Bagaimana Peranan Customer Service dalam memberikan pelayanan terhadap nasabah di Bank Nagari Cabang Siteba Padang"?

\section{LANDASAN TEORI}

Pengertian Bank

Menurut Undang-Undang Pasal 1 ayat 2 Undang-Undang No. 10 Tahun 1998 tentang perubahan Undang-Undang Republik Indonesi No. 7 tahun 1992 tentang perbankan: "Bank adalah badan usaha yang menghimpun dana dari masyarakat dalam bentuk simpanan dan menyalurkannya kembali kepada masyarakat dalam bentuk kredit dan atau bentuk-bentuk lainnya dalam rangka meningkatkan taraf hidup rakyat banyak."

Menurut Pasal 5 ayat 1 Undang-Undang No. 10 tahun 1998 yang merupakan perubahan Undang-Undang No. 7 tahun 1992 tentang Perbankan, membagi bank dalam 2 jenis yaitu :

1. Bank Umum yaitu bank yang melaksanakan kegiatan usaha secara konvensional dan atau berdasarkan prinsip syariah yang dalam kegiatan nyamemberikan jasa dalam lalulintas pembayaran.

2. Bank Perkreditan Rakyat yaitu bank yang melaksanakan kegiatan usahanya secara konvensional atau berdasarkan prinsip syariah yang dalam kegiatannya tidak memberikan jasa dalam lalulintas pembayaran.

Berdasarkan pendapat diatas, maka dapat ditarik kesimpulan, Bank adalah lembaga keuangan yang usaha pokoknya memberikan kredit dan jasa-jasa dalam lalulintas pembayaran.

Tujuan Bank

Berdasarkan Undang-Undang No. 10 tahun 1998 tentang perubahan UndangUndang Republik Indonesia No. 7 tahun 1992 tentang perbankan, Perbankan Indonesia dalam melakukan usahanya berasaskan demokrasi ekonomi dengan prinsip kehatihatian.Demokrasi ekonomi itu sendiri dilaksanakan berdasarkan Pancasila dan UndangUndang1945.

Berdasarkan asas yang diatas, maka tujuan perbankan Indonesia adalah menunjang pelaksanaan pembangunan nasional dalam rangka meningkatkan pemerataan pembangunan dan hasil-hasilnya, pertumbuhan ekonomi, dan stabilitas nasional ke arah peningkatan kesejahteraan rakyat banyak.

Fungsi Bank 
Fungsi utama bank adalah menghimpun dana dari masyarakat dan menyalurkannya kembali kepada masyarakat untuk berbagai tujuan atau sebagai financial intermediany.

Jenis - Jenis Bank

1. Bank Umum yaitu bank umum adalah bank yang melaksanakan kegiatan usaha secara konvensional dan atau berdasarkan prinsip syariah yang dalam kegiatannya memberikan jasa lalu lintar pembayaran. Sifat jasa yang diberikan adalah umum, dalam arti dapata memberikan seluruh jasa perbankan yang ada. Begitu juga dengan wilayah operasinya dapat dilakukan diseluruh wilayah. Bank umum disebut juga bank komersil (commercial bank).

2. Bank Perkreditan Rakyat ( BPR ) yaitu bank perkreditan Rakyat ( BPR ) adalah bank yang melaksakan kegiatan usaha secara konvensional atau berdasarkan prinsip syariah yang dalam kegiatannya tidak memberikan jasa dalam lalu lintas pembayaran. Artinya disini kegiatan BPR jauh lebih sempit jika dibandingkan dengan kegiatan bank umum.

Pengertian Customer Service

Customer Service adalah setiap kegiatan yang ditujukan untuk memberikan kepuasan melalui pelayanan yang diberikan seseorang kepada kliennya dalam menyelesaikan masalah dengan memuaskan.

Pelayanan nasabah atau Cutomer Service pada sebuah bank merupakan jasa yang diberikan oleh bank kepada nasabah pada khususnya dan masyarakat pada umumnya yang berkaitan dengan kegiatan usaha dan operasional bank sehari-hari. Terjadinya persaingan antar bank yang semakin ketat seperti sekarang ini, semua nasabah berkeinginan mendapatkan pelayanan yang terbaik dari bank melalui kemudahan berhubungan dengan bank, pelayanan yang cepat, dan keramahan petugas bank baik dari segi produk atau jasa yang ditawarkan maupun masalah pelayanan yang diberikan kepada nasabahnya.

Menurut Kasmir, 2004. Pengertian Customer Service secara umum adalah setiap kegiatan yang diperuntukan atau ditujukan untuk memberikan kepuasan kepada nasabah melalui pelayanan yang dapat memenuhi keinginan dan kebutuhan nasabah.

Customer Service memegang peranan sangat penting memberikan pelayanan dan dituntut untuk selalu berhubungan dengan nasabah dan menjaga hubungan itu tetap baik. Hal ini tentu saja harus dilakukan karena menjaga hubungan yang baik dengan nasabah juga berarti menjaga image bank agar citra bank dapat terus meningkat di mata nasabah.Customer Service bank dalam melayani para nasabah harus memiliki kemampuan melayani nasabah secara tepat dan cepat serta memiliki kemampuan berkomunikasi yang baik dengan diikuti dengan tersedianya sarana dan prasarana yang mendukung kecepatan, ketepatan, dan keakuratan pekerjaannya karena Customer Service merupakan pintu gerbang utama sebuah bank.

Tugas Customer Service

Dalam praktiknya fungsi Customer Service adalah sebagai resepsionis, sebagai deskman, sebagai salesman, sebagai Customer Relation Officer, sebagai Komunikator.

1. Sebagai Resepsionis Dalam hal ini, Customer Service bertugas menerima tamu atau nasabah yang datang ke bank dengan ramah, sopan, tenang, simpatik, menarik dan menyenangkan. Customer Service harus selalu memberi perhatian, berbicara dengan suara yang lembut dan jelas. Penggunaan bahasa yang mudah dimengerti serta mengucapkan salam. Misalnya "selamat pagi, "selamat siang" atau "selamat sore" sesuai dengan kondisi 
2. Sebagai Deskman Sebagai deskman, tugas Customer Service antara lain memberikan informasi mengenai produk-produk bank, antara lain menjelaskan manfaat dan ciri-ciri produk bank. Hal yang perlu juga dijelaskan adalah keunggulan produk kita dibandingkan dengan produk pesaing. Sebagai Deskman Tugas Customer Service juga harus menyiapkan berbagai brosur dan formulir untuk kepentingan nasabah. Kemudian menjawab pertanyaan nasabah mengenai produk bank serta membantu nasabah mengisi formulir aplikasi sesuai dengan transaksi yang ia lakukan.

3. Sebagai Salesman Sebagai Salesman, tugas Customer Service bank adalah berusaha sekuat tenaga menjual produk perbankan. Tugas lainnya adalah melakukan Cross Selling terhadap penjualan yang dilakukan. Sebagai penjual, Customer Servicemengadakan pendekatan danmencari nasabah baru. Berusaha membujuk nasabah yang baru serta berusaha mempertahankan nasabah yang lama.

4. Sebagai Customer Relation Officer yaitu hubungan dengan nasabah harus selalu dijaga melalui berbagai cara. Nasabah terkadang sering terpengaruh oleh hal yang dilakukan pesaing. Jika kita mengalami gangguan dengan nasabah, bukan tidak mungkin nasabah kita akan beralih ke bank pesaing kita. Dalam hal ini, tugas seorang Customer Service harus menjaga image bank dengan cara membina hubungan baik dengan seluruh nasabah sehingga nasabah merasa senang, puas dan makin percaya kepada bank. Hal yang terpenting adalah sebagai penghubung antara bank dengan seluruh nasabah.

5. Sebagai Komunikator yaitu tugas Customer Service yang terakhir adalah sebagai komunikator dengan cara memberikan segala informasi dan kemudahan-kemudahan kepada nasabah. Selain itu, juga sebagai tempat menampung keluhan, keberatan, atau konsultasi. Dalam arti yang lebih luas, tugas sebagai komunikator adalah mengkomunikasikan kepentingan bank dengan kepentingan nasabah. Mungkin ada komunikasi yang terputus-putus atau tersendat yang perlu diperbaiki. Komunikasi penting karena akan dapat mempererat hubungan antara nasabah dengan bank.

Dalam pelayanan di Bank Nagari Cabang Siteba Padang, Customer Service mempunyai tanggung jawab dalam menjelaskan tugasnya, sebagai berikut:

1. Melayani nasabah yang akan membuka rekening simpanan, membuat ATM, melaporkan buku tabungan atau cheque atau bilyet giro atau ATM hilang, meminta informasi saldo dan transaksi rekening, mencetak buku tabugan.

2. Melakukan identifikasi dan vertisifikasi identitas diri nasabah yang akan membuka rekening simpanan pada Bank Nagari Cabang Siteba Padang.

3. Mempersiapkan Dokumen-dokumen dan warkat-warkat yang berkaitan dengan pembukuan rekening giro, tabungan, deposito atau sertifikat deposito, penerbitan kartu ATM dan lain sejenisnya.

4. Menyimpan dan memelihara file dokumen-dokumen dan warkat-warkat yang berkaitan dengan pembukuan rekening simpanan dan transaksi keuangan nasabah.

5. Membantu nasabah untuk memastikan kelengkapan pengisian aplikasi transfer dan inkasso sebelum di teruskan kepada teller.

Pada dasarnya tugas Customer Service di bidang perbankan itu sama, yaitu berhubungan langsung dengan nasabah dalam memenuhi kebutuhannya yaitu membuka rekening, menyelesaikan masalah terkait dengan rekeningnya.Memasarkan produk dan jasa perbankan kepada nasabah. Di luar kegiatan, Customer Service juga membantu lobby untuk 
mendapatkan calon nasabah prioritas atau instansi yang potensial. Adapun persyaratan menjadi eorang Customer Service adalah sebagai berikut:

1. Persyaratan Fisik, yaitu:

a. Kesehatan yang prima.

b. Penampilan bersih dan rapi.

c. Suara merdu.

d. Gerak-gerik badan yang wajar.

2. Persyaratan Mental, yaitu:

a. Mempunyai rasa tanggung jawab yang besar.

b. Percaya diri.

c. Aktif dalam melayani nasabah.

3. Persyaratan Kepribadian, yaitu

a. Lemah lembut.

b. Ramah.

c. Mampu mengendalikan diri.

d. Tenaga dan tabah.

4. Persyaratan Sosial, yaitu

a. Pandai bergaul.

b. Murah tersenyum.

c. Mudah bekerja sama.

d. Lancar berbicara.

Sikap dan Perilaku Seorang Customer Service

Sikap dan perilaku merupakan bagian terpenting dalam perbankan. Adanya sikap dan perilaku yang harus di jalankan oleh setiap pegawai bank adalah jujur dalam bertindak dan bersikap, rajin, tepat waktu ,dan tidak pemalas, selalu murah senyum, lemah lembut dan ramah tamah, sopan santun tutur sapa dan hormat, bertanggung jawab dan suka menolong nasabah.

\section{METODE PENELITIAN}

Jenis penelitian yang digunakan peneliti dalam penelitian ini yaitu deskriptif kuantitatif, penelitian ini dilakukan di Bank Nagari Cabang Siteba Padang,

Dalam pengumpulan data dan bahan untuk melakukan penelitian ini, digunakan metode-metode pengumpulan data sebagai berikut:

1. Metode pengumpulan data

a. Studi lapangan ( Field Research)

Pada penelitian ini dilakukan dengan cara melakukan pengamatan langsung dan melakukan wawancara dengan pihak-pihak yang terkait.

b. Studi Kepustakaan ( Library Research)

Penelitian ini dilakukan dengan mengumpulkan data dan menggunakan teori-teori yang berkaitan dengan masalah-masalah yang akan di bahas, yang di peroleh dari literature yang ada berupa buku-buku yang berkaitan dengan masalah.

\section{HASIL DAN PEMBAHASAN}

Peranan seorang Customer Service dalam meningkatkan pelayanan terhadap nasabah pada Bank Nagari Cabang Siteba Padang merupakan kunci sukses dan dasar untuk 
membangun keberhasilan bank tersebut. Oleh Karena itu, segala kegiatan harus berjalan dengan baik dan bermutu demi terciptan yakepuasan nasabah. Karena nasabah yang merasa mendapatkan kepuasan akan kembali lagi mendatangi bank tersebut dan membeli produk lain yang ditawarkan oleh bank

Dalam praktiknya fungsi Customer Service adalah sebagai resepsionis, sebagai deskman, sebagai salesman, sebagai customer relation officer, sebagai komunikator.

Aktivitas Pembukaan Rekening dilakukan oleh Customer service di Bank Nagari Cabang Siteba Padang adalah sebagai berikut :

1. Pembukuan rekening dan penutupan rekening.

a. Rekening Giro.

b. Rekening Tabungan.

c. Deposito Berjangka.

2. Informasi saldo rekening giro dan tabungan.

3. Pemesanan dan mencetak buku cek atau bilyet giro dan tabungan.

4. Penyerahaan atau pengiriman buku cek atau bilyet giro.

5. Aktivitas lainnya non-tunai.

a. Memelihara dokumen.

b. Melakukan reminder.

c. Pemeliharaan data nasabah.

\section{SIMPULAN}

Berdasarkan uraian dan pembahasan yang telah dikemukakan dalam bab sebelumnya, maka dapat diambil kesimpulan sebagai berikut :

1. Customer Service adalah seorang komunikator dengan cara memberikan segala informasi dan kemudahan-kemudahan kepada nasabah dan juga sebagai tempat menampung keluhan, keberatan, atau konsultasi antara kepentingan bank dengan kepentingan nasabah.

2. Customer Service memegang peranan sangat penting dalam memberikan pelayanan dan ditunt utuntuk selalu berhubungan dengan nasabah dan menjaga hubungan itu tetap baik. Hal ini tentu saja harus dilakukan karena menjaga hubungan yang baik dengan nasabah juga berarti menjaga image bank agar citra bank dapat terus meningkat di mata nasabah.

3. Bahwasanya peran Customer Service dalam meningkatkan loyalitas nasabah sangatlah penting melalui pelayanan yang diberikan oleh bagian Customer Service. Pelayanan Customer Service berupa memberikan kemudahan kepada para nasabah. 


\section{DAFTAR PUSTAKA}

Budisanto, Totok dan Sigit Triandaru. 2000. Bank dan Lembaga Keuangan Lainnya. jakarta: Sinar Grafika.

Marlius, D. (2018). Loyalitas Nasabah Bank Nagari Syariah Cabang Bukittinggi Dilihat Dari Kualitas Pelayanan. Jurnal Pundi. Volume 1. No. 3. Hal.12-22. https://doi.org/10.31575/jp.v1i3.60

Fernandes, Y. D., \& Marlius, D. (2018). Peranan Customer Service Dalam Meningkatkan Pelayanan Kepada Nasabah Pada PT. Bank Pembangunan Daerah Sumatera Barat Cabang Utama Padang. https://doi.org/10.31227/osf.io/wrh3p

Kasmir. 2007. Dasar-Dasar Perbankan. PT. Raja Grafindo Persada.

Martini, William, B. 2004. Quality Customer Service. Jakarta: PPM.

Simorangkir, O.P. 1988. Seluk Beluk Bank Komersial. Jakarta: Aksara Persada Indonesia.

Sunarto, Helmi, S. 2008. Perencanaan Dan Pengembangan Bisnis. Medan: USU Press.

Undang-Undang No. 10 Tahun 1988 Tentang Perubahan Undang-Undang No. 7 Tahun 1992 Tentang Perbankan. 